\title{
Effects of low dissolved oxygen on zooplankton predation by the ctenophore Mnemiopsis leidyi
}

\author{
Mary Beth Decker ${ }^{1, *}$, Denise L. Breitburg ${ }^{2}$, Jennifer E. Purcell ${ }^{3}$ \\ ${ }^{1}$ Department of Ecology and Evolutionary Biology, Yale University, New Haven, Connecticut 06520-8106, USA \\ ${ }^{2}$ Smithsonian Environmental Research Center, PO Box 28, Edgewater, Maryland 21037, USA \\ ${ }^{3}$ Western Washington University, Shannon Point Marine Center, 1900 Shannon Point Road, Anacortes, Washington 98221, USA
}

\begin{abstract}
The occurrence of low dissolved oxygen (DO), caused by vertical stratification and excess nutrient inputs, is an important and widely occurring physical feature in aquatic systems. Because some gelatinous species, such as the lobate ctenophore Mnemiopsis leidyi are more tolerant of low DO concentrations than their prey and competitors, hypoxia may have profound effects on trophic interactions. Predation, clearance and digestion rates of ctenophores feeding on zooplankton (primarily Acartia tonsa) were measured at 1.0, 2.0, $3.0 \mathrm{mg} \mathrm{l}^{-1}$ and air-saturated (approximately $7 \mathrm{mg} \mathrm{l}^{-1}$ ) DO. Clearance of zooplankton by large ctenophores (mean $22.5 \mathrm{ml}$, range 7 to $46 \mathrm{ml}$ ) was greater at low DO concentrations than under normoxic conditions. In contrast, consumption of zooplankton by small (mean $2.9 \mathrm{ml}$, range 1 to $10 \mathrm{ml}$ ) M. leidyi did not differ among DO levels. Similarly, ctenophore digestion rates were unchanged at oxygen concentrations as low as $1 \mathrm{mg} \mathrm{l}^{-1}$. Jumping frequency of $A$. tonsa copepods decreased significantly with decreasing DO concentration (1.0, 2.0, $3.0 \mathrm{mg} \mathrm{l}^{-1}$ and air-saturated). Such changes in prey behavior in low DO could affect both encounter and capture rates, potentially making less-tolerant prey more vulnerable to predation in hypoxic waters. Gelatinous species, which are more tolerant of hypoxia than fishes, may be able to inhabit regions of low oxygen that are avoided by zooplanktivorous fishes with high oxygen requirements. This could lead to dominance of gelatinous predators in areas affected by severe hypoxia and might alter energy pathways in these systems.
\end{abstract}

KEY WORDS: Hypoxia $\cdot$ Feeding $\cdot$ Digestion $\cdot$ Zooplankton $\cdot$ Acartia tonsa $\cdot$ Copepod $\cdot$ Chesapeake Bay

Resale or republication not permitted without written consent of the publisher

\section{INTRODUCTION}

The persistent or episodic occurrence of low dissolved oxygen (DO, hypoxia) is an important physical feature of many aquatic habitats including estuaries, lakes, nearshore coastal waters, fjords and the oxygen minimum layer of the deep-sea. In shallow marine systems, hypoxia (i.e. dissolved oxygen concentrations $<2 \mathrm{mg} \mathrm{l}^{-1}$ ) generally occurs during summer when density stratification of the water column limits re-aeration of bottom waters (Renaud 1986, Turner et al. 1987, Swanson \& Parker 1988, Rabalais et al. 1991). Subpycnocline waters can become severely hypoxic or anoxic during summer due to microbial respiration, while oxygen concentrations at the surface can be sat- urated or supersaturated as a result of algal photosynthesis (Taft et al. 1980, Sanford et al. 1990, Jonas 1992, Rabalais et al. 2002). Oxygen depletion in estuaries and coastal waters is often exacerbated by excess nutrient loadings (Officer et al. 1984, Elmgren 1989, Rosenburg et al. 1990, Boesch et al. 2001, Rabalais et al. 2002), and is a major threat to the ecology and fisheries of coastal waters worldwide (Caddy 1993). The range and occurrence of oxygen depletion appear to be increasing in shallow coastal and estuarine regions (Diaz 2001) and hypoxia is predicted to become more common as a result of global warming (Kennedy 1990). A large proportion of the water in Chesapeake Bay and its tributaries becomes hypoxic or anoxic for periods lasting hours to months in summer (Sanford et al. 
1990). On average, about $62 \%$ of the subpycnocline water volume in the main Chesapeake Bay (including Mobjack Bay, but excluding Tangier Sound) is < $5 \mathrm{mg}$ $\mathrm{l}^{-1}$, and about $19 \%$ of the subpycnocline volume is $<2 \mathrm{mg} \mathrm{l}^{-1}$ (M. Olson, Chesapeake Bay Program, pers. comm.). Thus, hypoxia is a stress that is encountered by many organisms in this ecosystem.

Not only does low DO have direct effects on mortality of organisms (reviewed in Marcus 2001 and Breitburg et al. 2001, Miller et al. 2002), but it can have indirect effects on mortality through predator-prey interactions. Motile species may shift their horizontal or vertical distribution in both freshwater and coastal systems influenced by hypoxia (Rudsam \& Magnuson 1985, Kolar \& Rahel 1993, Roman et al. 1993, Breitburg et al. 1994, Howell \& Simpson 1994, Keister et al. 2000, Bell et al. 2003). Such differential shifts in the distributions of predators and prey potentially change the rates at which they encounter each other (Breitburg et al. 1999). In addition, prey-capture rates can be affected by hypoxia due to decreased foraging activity of predators (Bejda et al. 1987, Breitburg et al. 1994, Petersen \& Pihl 1995, Taylor \& Eggleston 2000) and changes in the behaviors of prey that make them more susceptible to predation (Poulin et al. 1987, Rahel \& Kolar 1990, Pihl et al. 1992, Kolar \& Rahel 1993, Breitburg et al. 1997, Taylor \& Eggleston 2000). For example, predation by Chrysaora quinquecirrha medusae feeding on fish larvae was greater at low DO, presumably because the larvae escaped poorly when stressed; however, medusa predation on fish eggs, which cannot escape, was unaffected by low DO. In contrast, predation by juvenile striped bass Morone saxatilis feeding on fish larvae was reduced at low DO (Breitburg et al. 1994, 1997).

Hypoxia has differential effects on Chesapeake Bay organisms. For example, the lobate ctenophore Mnemiopsis leidyi is more tolerant of hypoxia than its prey and than other predators in the Chesapeake food web (Purcell et al. 2001a, Breitburg et al. 2003). Ctenophore survival was $100 \%$ at DO concentrations $\geq 0.5 \mathrm{mg} \mathrm{l}^{-1}$ in both $30 \mathrm{~h}$ and $72 \mathrm{~h}$ trials. In contrast, $24 \mathrm{~h} \mathrm{LC} \mathrm{L}_{50}$ estimates for the calanoid copepod Acartia tonsa range from 0.95 to $1.4 \mathrm{mg} \mathrm{l}^{-1}$ (Roman et al. 1993, Stalder \& Marcus 1997). In addition, $\mathrm{LC}_{50}$ estimates for most Chesapeake Bay fishes range between 0.5 and $2.5 \mathrm{mg} \mathrm{l}^{-1}$ (reviewed in Breitburg et al. 2001, 2003). Because gelatinous and non-gelatinous species differ in their physiology and their oxygen demand, their behavior (i.e. predatory or escape capabilities) may be affected differently by low DO concentrations. It is possible that ctenophores may increase prey consumption or outcompete potential competitors such as the scyphomedusa Chrysaora quinquecirrha and the bay anchovy Anchoa mitchilli in hypoxic waters where they co- occur. Thus, the effects of low DO on ctenophores, as well as on their prey and competitors, may dramatically impact trophic interactions in the water column (Breitburg et al. 1999, Purcell et al. 2001a).

Mnemiopsis leidyi is an important predator of zooplankton and ichthyoplankton in Chesapeake Bay and its tributaries (Cowan \& Houde 1992, 1993, Purcell et al. 1994a,b, 2001b, Purcell \& Decker 2005). M. leidyi is a cruising predator that captures prey within their outstretched lobes and tentillae (Waggett \& Costello 1999). Consumption by $M$. leidyi at some times and regions may reduce copepod populations in the mainstem Chesapeake Bay, particularly when its predator Chrysaora quinquecirrha is scarce (Purcell et al. 2001b, Purcell \& Decker 2005).

The vertical distributions of Mnemiopsis leidyi ctenophores and Acartia tonsa copepods overlap in hypoxic waters. $M$. leidyi and zooplankton are abundant in bottom waters when bottom oxygen concentrations are $>2 \mathrm{mg} \mathrm{l}^{-1}$ (Keister et al. 2000). Copepods are present in the bottom layer when DO $<2.5$ to $3.0 \mathrm{mg} \mathrm{l}^{-1}$, but at reduced densities, and $M$. leidyi can be abundant at DO concentrations as low as $1.3 \mathrm{mg}^{-1}$. The influence of hypoxia on the predatory behavior of $M$. leidyi has recently been investigated in the laboratory (S. Kolesar et al. unpubl. data). We are only beginning to understand how interactions between this key predator and its planktonic prey are influenced by low DO concentrations.

In this study, we examine the effects of low DO on zooplankton predation by Mnemiopsis leidyi. Interactions between this important predator and its major summer prey, Acartia tonsa, are typical of food webs in the mesohaline regions of Chesapeake Bay as well as in other estuaries along the Atlantic coast. Results from our work can be used to predict effects of hypoxia on plankton dynamics in seasonally-hypoxic estuaries.

\section{MATERIALS AND METHODS}

Experimental animals. Ctenophores were collected with a dip-net from the mesohaline Patuxent River 1 to $4 \mathrm{~d}$ prior to experiments. Test individuals were held at ambient conditions $\left(23^{\circ} \mathrm{C}, 13\right.$ to 15 salinity) in 751 aquaria that were gently mixed by surface paddles. Ctenophores were fed zooplankton (mainly Acartia tonsa and Artemia sp.), but not fed for $24 \mathrm{~h}$ prior to all experiments.

Zooplankton reared in $1 \mathrm{~m}^{3}$ mesocosms at the Academy of Natural Sciences Estuarine Research Center were used as prey in predation and digestion experiments. The mesocosms were filled with raw water from the Patuxent River flowing through a $1 \mathrm{~mm}$ mesh, which allowed eggs and other stages from natural field 
assemblages of zooplankton to enter the mesocosms To promote algal growth and zooplankton reproduction, nutrients were added to the mesocosm at levels of $16 \mu \mathrm{mol} \mathrm{l} \mathrm{l}^{-1}$ nitrogen and $1 \mu \mathrm{mol} \mathrm{l} \mathrm{l}^{-1}$ phosphorus. There was a $10 \%$ water change $\mathrm{d}^{-1}$ and nutrients were added daily to maintain desired levels. On the day prior to the experiments, zooplankton (dominated by Acartia tonsa) were collected from mesocosms with a $202 \mu \mathrm{m}$ net and held overnight in aquaria at $23^{\circ} \mathrm{C}, 13$ to 15 salinity in the laboratory.

Field-collected adult and late copepodite stages of Acartia tonsa were used for the behavioral studies. Copepods were collected from the mesohaline Choptank River 1 to $2 \mathrm{~d}$ prior to behavioral observations by slowly towing a $178 \mu \mathrm{m}$ mesh net horizontally at 0 to $2 \mathrm{~m}$ depth. Copepods from the solid $1 \mathrm{l}$ cod-end bucket were diluted immediately in a $20 \mathrm{l}$ container and then transferred to $75 \mathrm{l}$ aquaria filled with $1 \mu \mathrm{m}$ filtered Choptank water $\left(25^{\circ} \mathrm{C}, 15\right.$ salinity).

Effects of dissolved oxygen on ctenophore predation on zooplankton. We filled 8 experimental containers (plastic garbage cans) to $90 \mathrm{l}$ with $0.2 \mu \mathrm{m}$ filtered water from the mesohaline Patuxent River. Lids were taped shut, and water in the containers was bubbled with either $\mathrm{N}_{2}$ (low-oxygen treatments) or air (airsaturated treatments) to obtain the desired DO concentrations. DO concentrations were monitored using YSI (Models 52 and 85) dissolved oxygen meters. When a container reached its target DO concentration, the airstone was removed from the water and allowed to hang in the airspace above the water. The leakage of $\mathrm{N}_{2}$ into the airspace ensured displacement of air and maintenance of stable water-oxygen concentrations. Consumption of zooplankton by ctenophores was measured at 1.0, 2.0, $3.0 \mathrm{mg} \mathrm{l}^{-1}$ and air-saturated (approximately $7 \mathrm{mg} \mathrm{l}^{-1}$ ) DO concentrations. The $1.0 \mathrm{mg} \mathrm{l}^{-1} \mathrm{DO}$ treatment was tested to include the lower portion of the DO range at which ctenophores and copepods occasionally co-occur (Keister et al. 2000). DO concentrations below $1.0 \mathrm{mg} \mathrm{l}^{-1}$ were not tested because increased mortality of Acartia tonsa is observed when they are held at or below $0.9 \mathrm{mg} \mathrm{l}^{-1}$ for $24 \mathrm{~h}$ (Stalder \& Marcus 1997). The experiment was conducted on June 4, 9 and 16, 1999 and on August 2 and 30, 2000; 2 replicates of each DO concentration were completed on each date.

Prey used in the predation experiment were predominantly adult and late copepodite stages of Acartia tonsa. Zooplankton were divided into 8 portions with an unbiased plankton splitter and $1 / 8$ added into each of the experimental containers once the target oxygen concentrations had been attained. We then placed 8 to 12 ctenophores gently into a 21 acclimation chamber that excluded zooplankton (mesh size $35 \mu \mathrm{m}$ ) within each experimental tank, the containers were resealed, and the ctenophores and zooplankton were allowed to acclimate for $1 \mathrm{~h}$. Ctenophores were then released into the test arena and allowed to feed for $1 \mathrm{~h}$. Experiment duration was limited to $1 \mathrm{~h}$ because this is the average time it takes for Mnemiopsis mccradyi (possibly the same species as $M$. leidyi, K. Bayha pers. comm.) to digest 1 to 10 adult Acartia sp. (Larson 1987). During the course of the experiments, DO concentrations in the low-oxygen treatments were maintained within a mean of $0.09 \mathrm{mg} \mathrm{l}^{-1}( \pm 0.01 \mathrm{SE})$ of the targeted levels.

At the end of the experiment, both predators and prey were removed from the experimental containers. Ctenophores were dipped from the containers with an aquarium net, their individual displacement volumes were measured, and they were immediately preserved in $5 \%$ buffered formalin. Water was siphoned from each container, and zooplankton were collected in a $35 \mu \mathrm{m}$ mesh bag. Prior to preservation in $5 \%$ formalin, zooplankton were stained with neutral red (Dressel et al. 1972, Fleming \& Coughlan 1978) so that their condition during the experiment could later be scored as alive or dead. The number of living copepods plus those found in the ctenophores' gut contents was used to calculate prey density in each experimental container. Ctenophore volumes, prey densities, DO concentrations and temperatures for each treatment are reported in Table 1 . The number of prey added to 1 of the $2.0 \mathrm{mg} \mathrm{l}^{-1}$ containers on June 16, 1999 was anomalously high due to an error made while splitting the zooplankton, and these results were excluded from analyses on predation rates.

Consumption rates were measured by examining ctenophore gut contents. Prey items consumed were identified and counted while viewing the entire gut contents with a dissecting microscope. Size-specific predation rates were calculated for each ctenophore as the number of prey items eaten $\mathrm{h}^{-1} \mathrm{ml}^{-1}$ ctenophore volume. The mean predation rate of ctenophores within each experimental container was calculated and used as the response variable in statistical analyses. We also calculated clearance rates $\left(1\right.$ cleared $h^{-1}$ ctenophore $^{-1}$ ) by dividing predation rates (no. prey eaten individual ${ }^{-1} \mathrm{~h}^{-1}$ ) by initial prey densities (no. prey $\mathrm{l}^{-1}$ ). Size-specific clearance rates (l cleared $\mathrm{h}^{-1} \mathrm{ml}^{-1}$ ctenophore) were calculated for each ctenophore by dividing the liters cleared $\mathrm{h}^{-1}$ ctenophore ${ }^{-1}$ by the individual ctenophore volume $(\mathrm{ml})$.

Nested analysis of variance (ANOVA) was conducted to examine variance in predation rates between DO treatments, prey densities and days. We employed the model 'predation rate $=$ prey density $+\mathrm{DO}+$ prey density $\times \mathrm{DO}+$ date(DO)'. After ensuring that the slopes were not heterogeneous (i.e. a non-significant interaction term) and that there was no effect of day, the nested ANOVA was simplified to an analysis of covari- 
Table 1. Mnemiopsis leidyi. Conditions in experiments testing predation by ctenophores on prey, primarily Acartia tonsa copepods. Values are means $\pm 1 \mathrm{SE}$ of the mean. Air-sat: air-saturated (approximately $7 \mathrm{mg} \mathrm{l}^{-1}$ dissolved oxygen)

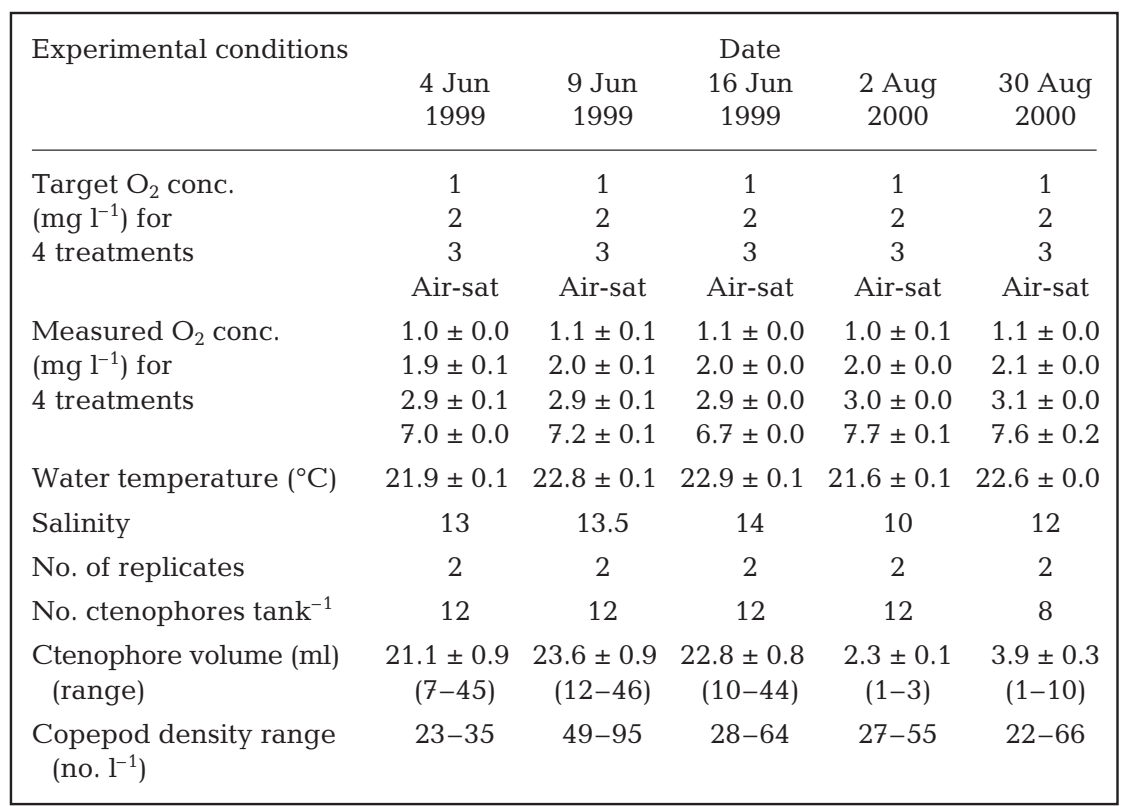

the feeding containers. At $25 \mathrm{~min}$ intervals, 5 to 6 ctenophores were removed from each of the digestion containers and the number of whole copepods and intact carapaces in their guts were counted with a dissecting microscope. Martinussen \& Båmstedt (1999) showed no significant relationships between digestion time and size of a similar lobate ctenophore, Bolinopsis infundibulum. Use of small, transparent ctenophores allowed easy visual inspection of gut contents. Different individuals were sampled at each 25 min interval. We calculated the average number of prey items present ctenophore ${ }^{-1}$ at the initial sampling period and then at each 25 min interval thereafter. This experiment was run twice, on July 2 and 9, 1999. The results of the digestion experiment were ance (ANCOVA) to allow examination of variation in predation rates due to DO and prey density. In addition, we used 1-way ANOVA to examine variance in clearance rates between DO treatments. Rank transformations were used where log- and square-root transformations still left variances heterogeneous.

Effects of dissolved oxygen on ctenophore digestion rates. Because gut-content analyses were used to estimate predation rates, it was necessary to determine whether DO concentrations influenced the time required by ctenophores to digest zooplankton. In order to measure digestion rates of Mnemiopsis leidyi feeding on zooplankton (primarily Acartia tonsa), eight 111 glass aquaria were filled with $0.2 \mu \mathrm{m}$ filtered Patuxent River water. Conditions were constant in each treatment (mean water temperature $=21.8^{\circ} \mathrm{C}, \mathrm{SE}=0.2$, mean salinity $=14.5, \mathrm{SE}=0.2$ ). Prior to the addition of ctenophores and zooplankton, the aquaria were sealed and bubbled with either $\mathrm{N}_{2}$ (low-oxygen treatments) or air (air-saturated treatments) to obtain the desired DO concentrations. Digestion rates were measured at 1.0, 2.0 and $3.0 \mathrm{mg} \mathrm{l}^{-1}$ and air-saturated DO. Once the target DO levels had been attained, 50 ctenophores (mean individual volume $1.5 \mathrm{ml}$ ) were gently added to each of 4 aquaria. Ctenophores were allowed to acclimate for $1 \mathrm{~h}$ before copepods were added at a density of roughly $200 \mathrm{l}^{-1}$. After ctenophores had fed for $10 \mathrm{~min}$, they were removed with an aquarium net, gently dipped in filtered Patuxent River water to remove any uneaten copepods, and then transferred into another 4 aquaria with the same 4 DO concentrations as analyzed using the model 'no. prey ctenophore ${ }^{-1}=$ Time + DO + Time $\times$ DO + Date' to allow examination of variation in digestion rates due to DO and date and to test for differences in digestion rates among DO treatments.

In order to ensure that ctenophores were digesting prey in hypoxic water and not simply expelling their gut contents, we continuously observed digestion by individual ctenophores in a 1.51 watch-glass at a range of DO concentrations. The watch-glass and an 111 aquarium were filled with $0.2 \mu \mathrm{m}$-filtered Patuxent River water (21 to $23^{\circ} \mathrm{C}, 11$ to 12 salinity), covered with clear Plexiglas and sealed, and DO concentrations (1.0, 2.0, $3.0 \mathrm{mg} \mathrm{l}^{-1}$ and air-saturated) were obtained as before. We used a peristaltic pump to fill the sealed watch-glass and gently circulate water between the aquarium and the watch-glass to maintain target oxygen levels. DO concentrations in the watch-glass were monitored with an oxygen microelectrode throughout the observation period. Ctenophores were fed until they had consumed 2 to 12 adult Acartia tonsa, and then 2 were gently placed in the watch-glass. Digestion of copepods was observed at 1 low-DO treatment and 1 air-saturated control on 3 d in July 2000. Observations continued until gut contents were no longer recognizable.

Effects of dissolved oxygen on copepod behavior. The swimming behavior of Acartia tonsa in filtered water has been described as monotonic jumping (Tiselius \& Jonsson 1997). To assess how normal swimming behavior of Acartia tonsa may have been 
affected during our predation experiments, we examined how jumping frequency of free-swimming copepods was influenced by DO concentrations. An aquarium $(36 \mathrm{~cm} \times 14 \mathrm{~cm} \times 10 \mathrm{~cm}, 5$ l) filled with $1 \mu \mathrm{m}$-filtered Choptank River water was sealed, and target DO concentrations were obtained as before. Observations were conducted at 1.0, 2.0, 3.0 $\mathrm{mg} \mathrm{l}^{-1}$ and air-saturated DO. Copepods (approximately $200 \mathrm{l}^{-1}$ ) were then placed in the aquarium and allowed to acclimate for $1 \mathrm{~h}$. Copepods were filmed using a Sony CCD TR400 Hi8 video-recorder with a variable focus lens (5.4 to 64.8 $\mathrm{mm})$. The aquarium was illuminated from behind using an infrared light (IR) source (STA Model Mir 3 Infra-red, wavelength $>700 \mathrm{~nm}$, Aspect Technology and Equipment) because zooplankton are most sensitive to light with $<700 \mathrm{~nm}$ wavelengths (Sterns \& Forward 1984, Forward 1988) and therefore, IR should not have influenced copepod behavior. The positions of the camcorder and IR light were moved horizontally every 10 minutes in order to film copepods in a different region of the aquarium. We filmed for a total of $2 \mathrm{~h}$ at each DO treatment.

Jumping frequencies were determined by counting the number of jumps of an individual copepod for 1 min or until it left the field of view. We chose 100 individuals arbitrarily from the videotape footage for each DO treatment. Container size was large compared with the size of the copepods (ca $0.5 \mathrm{~mm}$ carapace length), and no copepods near the aquarium walls were used to minimize the effects of the container on their behavior. To test for the effect of DO on copepod jumping frequencies, we conducted a linear regression on the mean jumping frequency in each DO treatment. It is unlikely that in a relatively large container the behavior of one copepod would affect the behavior of other copepods, thus each observation was considered to be an independent measure of jumping frequency.

\section{RESULTS}

\section{Effects of low dissolved oxygen on ctenophore predation on zooplankton}

Large ctenophores were unavailable for collection in 2000; thus, ctenophore sizes differed dramatically in 1999 and 2000 predation experiment replicates (Table 1). Because small ctenophores ingest more per unit volume than large ctenophores (Kremer 1979, Kremer \& Reeve 1989), we examined DO effects on ctenophore predation and clearance rates separately for 1999 and 2000. Neither date nor interactions (between prey density and DO) were significant in either year (all $p>0.28$ ) in tests using the full ANOVA model; therefore we present results of the simplified ANCOVA model testing only the main effects. Inspection of statistical analyses indicated significant effects of prey density $(F=71.48, \mathrm{df}=1, \mathrm{p}<0.001)$, and a trend toward higher predation rates at moderate levels of hypoxia (2.0 and $3.0 \mathrm{mg} \mathrm{l}^{-1}$ ) than at $1 \mathrm{mg} \mathrm{l}^{-1}$ and air-saturation during 1999 (Fig. $1 \mathrm{~A}_{i} F=3.12$, df = 3, $\mathrm{p}=0.052)$. In contrast, neither prey density $(F=3.43$,

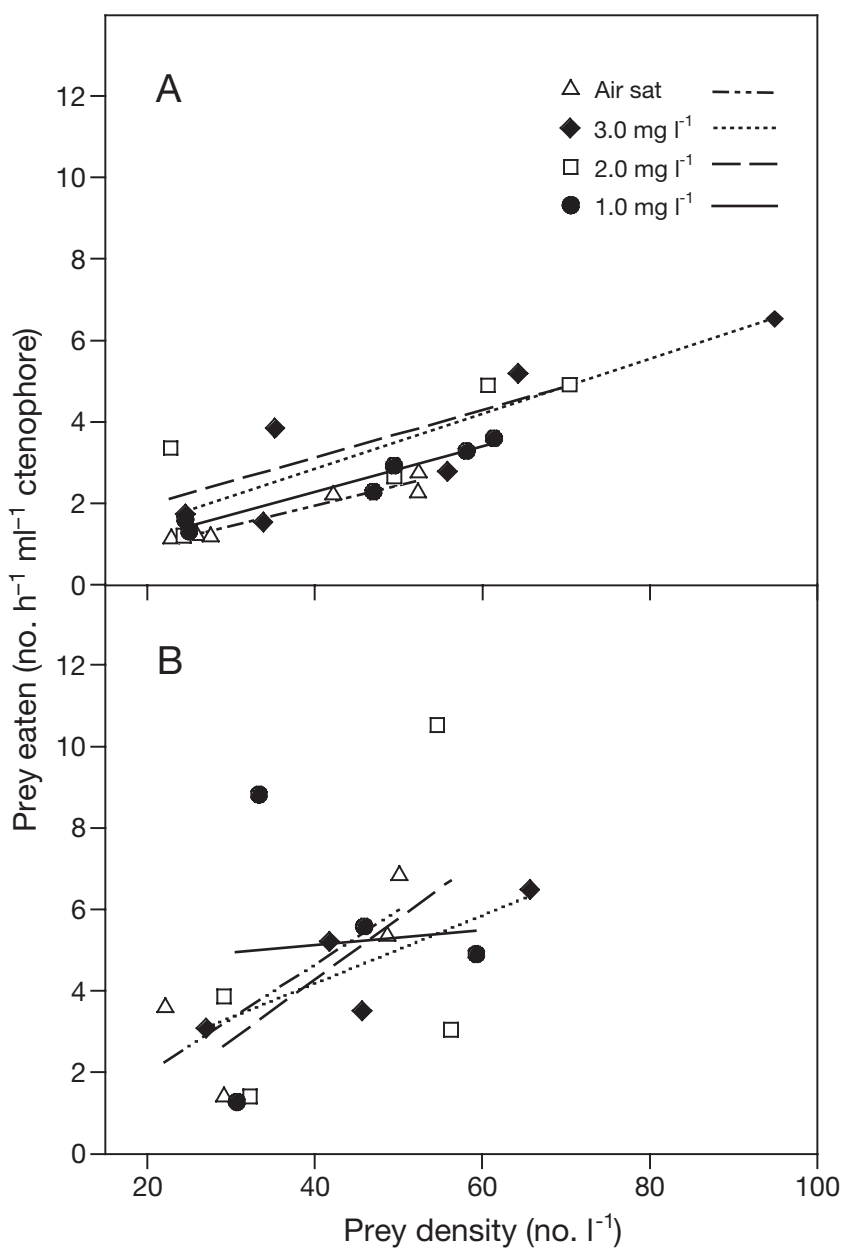

Fig. 1. Mnemiopsis leidyi. Numbers of zooplankton prey (primarily Acartia tonsa adults and copepodites) consumed by ctenophores during $1 \mathrm{~h}$ experiment in reduced (1.0, 2.0 and $3.0 \mathrm{mg} \mathrm{l}^{-1}$ ) and air-saturated (approximately $7 \mathrm{mg} \mathrm{l}^{-1}$ ) dissolved oxygen concentrations in (A) 1999 and (B) 2000. Data points: average no. of prey eaten $\mathrm{h}^{-1} \mathrm{ml}^{-1}$ ctenophore vol versus experimental prey densities (no. $\mathrm{l}^{-1}$ ) for each replicate; lines: relationships between prey consumption and prey density for each oxygen treatment (1999: $y_{1.0}=0.06 x+0.28$, $\mathrm{R}^{2}=0.95, t=8.41, \mathrm{df}=4, \mathrm{p}=0.001 ; y_{2.0}=0.06 x+0.77, \mathrm{R}^{2}=0.61$ ， $t=2.18, \mathrm{df}=3, \mathrm{p}=0.12 ; Y_{3.0}=0.07 x+0.15, \mathrm{R}^{2}=0.78, t=3.76$, $\mathrm{df}=4, \mathrm{p}=0.02 ; y_{\text {Air-sat }}=0.05 x-0.07, \mathrm{R}^{2}=0.93, t=7.34, \mathrm{df}=4$, $\mathrm{p}=0.002 .2000: y_{1.0}=0.02 x+4.36, \mathrm{R}^{2}=0.01, t=0.11, \mathrm{df}=2$, $\mathrm{p}=0.92 ; y_{2.0}=0.15 x-1.75, \mathrm{R}^{2}=0.29, t=0.90, \mathrm{df}=2, \mathrm{p}=0.46 ;$ $y_{3.0}=0.08 x+0.80, \mathrm{R}^{2}=0.71, t=2.24, \mathrm{df}=2, \mathrm{p}=0.15 ; y_{\text {Air-sat }}=$ $0.13 x-0.73, \mathrm{R}^{2}=0.64, t=1.89, \mathrm{df}=2, \mathrm{p}=0.20$ ). Experimental conditions summarized in Table 1 
Table 2. Mnemiopsis leidyi. Mean $( \pm \mathrm{SE})$ size-specific clearance rates (l cleared $\mathrm{h}^{-1} \mathrm{ml}^{-1}$ ctenophore) of ctenophores eating zooplankton, primarily Acartia tonsa copepods, at various dissolved oxygen treatments in 1999, 2000 and in both years combined

\begin{tabular}{|lllll|}
\hline Year & $1.0 \mathrm{mg} \mathrm{l}^{-1}$ & $2.0 \mathrm{mg} \mathrm{l}^{-1}$ & $3.0 \mathrm{mg} \mathrm{l}^{-1}$ & Air-saturated \\
\hline 1999 & $0.06 \pm 0.00$ & $0.08 \pm 0.01$ & $0.07 \pm 0.01$ & $0.05 \pm 0.00$ \\
2000 & $0.13 \pm 0.05$ & $0.11 \pm 0.04$ & $0.10 \pm 0.01$ & $0.11 \pm 0.03$ \\
Both & $0.09 \pm 0.02$ & $0.09 \pm 0.02$ & $0.08 \pm 0.01$ & $0.07 \pm 0.01$ \\
\hline
\end{tabular}

$\mathrm{df}=1, \mathrm{p}=0.09)$, nor DO $(F=0.06, \mathrm{df}=3, \mathrm{p}=0.98)$ had significant effects on predation rate in 2000.

The results of the predation experiment showed no ctenophore satiation in hypoxic conditions at the range of prey densities tested (Fig. 1). We therefore examined variation in ctenophore clearance rates $\left(1\right.$ cleared $h^{-1}$ $\mathrm{ml}^{-1}$ ctenophore volume) among DO treatments using ANOVA. A 1-way ANOVA on ranks indicated differences in clearance rates among DO treatments in 1999 $(F=4.87, \mathrm{df}=3, \mathrm{p}=0.01)$, but not in $2000(F=0.02, \mathrm{df}=3$, $\mathrm{p}=0.99)$ (Table 2). A Student-Newman-Keuls multiplecomparison test revealed that in 1999 clearance rates in all low-DO treatments were higher than those in the airsaturated controls (Table 2). Thus, our data indicate that predation by large ctenophores $($ mean $=22.5 \mathrm{ml}$, range $=$ 7 to $46 \mathrm{ml}$ ) was greater at low-DO concentrations than in air-saturated conditions; however, small ctenophores (mean $2.9 \mathrm{ml}$, range $=1$ to $10 \mathrm{ml}$ ) showed no differences in predation among DO treatments.

We estimated the average clearance by Mnemiopsis leidyi (average size $=15.5 \mathrm{ml}$, size range 1 to $46 \mathrm{ml}$,

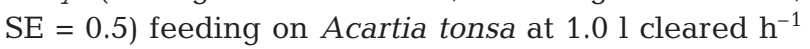
ctenophore $^{-1}\left(\mathrm{SE}=0.1\right.$, range 0.1 to $2.4 \mathrm{l}$ cleared $\mathrm{h}^{-1}$ ctenophore $^{-1}$ ). At experimental prey densities ranging from 22 to 121 copepods $\mathrm{l}^{-1}$, this is equivalent to $0.3-10.5 \% \mathrm{~h}^{-1}$ (average $2.5 \% \mathrm{~h}^{-1}, \mathrm{SE}=0.3$ ) or an average of 46.7 copepods eaten $\mathrm{h}^{-1}$ ctenophore ${ }^{-1}$.

\section{Effects of low dissolved oxygen on ctenophore digestion rates}

Results of the ANCOVA revealed that there was no effect of date on the number of prey consumed ctenophore ${ }^{-1}$ throughout the timed digestion experiment (Table 3); therefore, we combined data from both days for further analyses. The numbers of prey present in the ctenophore guts decreased over time, with few prey remaining at $150 \mathrm{~min}$ (Fig. 2). The average number of prey present in ctenophores was 4.1 ( $\mathrm{SE}=0.5$, range 1 to 11 ) at the start of the experiment and 0.4 ( $\mathrm{SE}=0.1$, range 0 to 4 ) after $150 \mathrm{~min}$. In order for linear models to be used in the regression and slope analyses, data for the final time interval (i.e. $200 \mathrm{~min}$ ) were omit- ted. Data for all 4 DO treatments then fit significant linear regressions. The slopes of the regressions were not significantly different (Table 4, ANOVA, heterogeneity of slopes, $F=0.66, \mathrm{df}=21, \mathrm{p}=0.84$ ), providing no evidence for differences in digestion rates among the DO treatments.

Observations of 12 individual ctenophores digesting copepods revealed that no ctenophores expelled their gut contents after an average of $51.5 \mathrm{~min}$ ( $\mathrm{SE}=7.1$, range 25 to 91 ) in any treatment. During these observations, ctenophores ingested similar numbers of copepods ( $6.3 \pm 0.9$, range 2 to 12$)$ and conditions were similar to those in the preceding experiment (water temperature $=21.9^{\circ} \mathrm{C} \pm 0.5$, salinity $=11.6 \pm 0.2$ ) and in all treatments. Temperatures during the observations

Table 3. Mnemiopsis leidyi. Variation in digestion rates of copepods (Acartia tonsa) by ctenophores as a function of dissolved oxygen (DO) and date. Analysis tested for effects of DO and date on number of prey present ctenophore ${ }^{-1}$ throughout the timed digestion experiment. The model 'no. prey ctenophore ${ }^{-1}=$ time $+\mathrm{DO}+$ time $\times \mathrm{DO}+$ Date' $^{\prime}$ was employed, whereby interaction term tests for heterogeneity of slopes (i.e. differences in digestion rates among DO treatments)

\begin{tabular}{|lrrrc|}
\hline Source & df & SS & $F$ & $p$ \\
\hline Time & 7 & 156.1 & 10.7 & $<0.0001$ \\
DO & 3 & 12.3 & 2.0 & 0.14 \\
DO $\times$ Time & 21 & 28.8 & 0.7 & 0.84 \\
Date & 1 & 0.03 & 0.01 & 0.90 \\
\hline
\end{tabular}

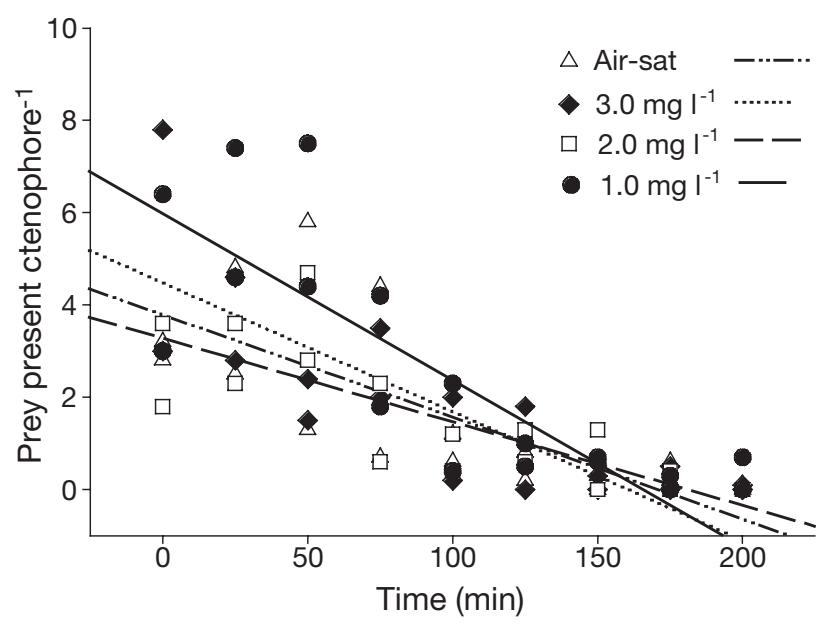

Fig. 2. Mnemiopsis leidyi. Effects of dissolved oxygen (DO) concentration on digestion of zooplankton by ctenophores. Water temperature during experiment averaged $21.8^{\circ} \mathrm{C}$ $( \pm 0.2 \mathrm{SE})$. Data points: average no. of prey present ctenophore $^{-1}$ for each replicate during course of digestion experiment; lines: relationships between number of prey ctenophore $^{-1}$ and time $(\leq 175 \mathrm{~min})$ for each oxygen treatment $\left(y_{1.0}=\right.$ $-0.04 x+5.98 ; y_{2.0}=-0.02 x+3.27 ; y_{3.0}=-0.03 x+4.47 ; y_{\text {Air-sat }}=$ $-0.02 x+3.78)$. Parameters of regression analyses in Table 4 
Table 4. Mnemiopsis leidyi. Results of linear regressions of number of prey (Acartia tonsa) present in ctenophore guts over time during digestion in dissolved oxygen (DO) treatments (Fig. 2). Fit of each linear regression was significant for each DO treatment; therefore, comparisons were made between lines in order to test for effect of DO concentration on digestion of prey. Heterogeneity of slopes analysis revealed that slopes of the regressions were not significantly different, indicating that $M$. leidyi digestion rates did not differ among DO treatments

\begin{tabular}{|lcccccc|}
\hline $\begin{array}{l}\text { Dissolved oxygen } \\
\text { treatment }\end{array}$ & $\mathrm{R}^{2}$ & Slope & $t$ & $\mathrm{df}$ & $\mathrm{p}$ \\
\hline $1.0 \mathrm{mg} \mathrm{l}^{-1}$ & 0.66 & -0.04 & -5.29 & 14 & $<0.001$ \\
$2.0 \mathrm{mg} \mathrm{l}^{-1}$ & 0.57 & -0.02 & -4.31 & 14 & $<0.009$ \\
$3.0 \mathrm{mg} \mathrm{l}^{-1}$ & 0.63 & -0.03 & -4.86 & 14 & $<0.001$ \\
Air-saturated & 0.46 & -0.02 & -3.73 & 14 & $<0.002$ \\
\hline
\end{tabular}

of individual ctenophores were not significantly different from conditions in the preceding digestion experiment (Student's $t=-0.53$, df $=12, \mathrm{p}=0.6$ ); however, salinities were lower than during the previous experiment in 1999 (Mann-Whitney rank sum $T_{6,8}=21, \mathrm{p}=$ 0.001 ), and reflected differences in the salinity of the Patuxent River during the time of the 2 experiments.

\section{Effects of low dissolved oxygen on copepod behavior}

Behavior of Acartia tonsa was significantly affected by DO concentration (Fig. 3). Mean jump frequency increased with increasing DO concentration from a

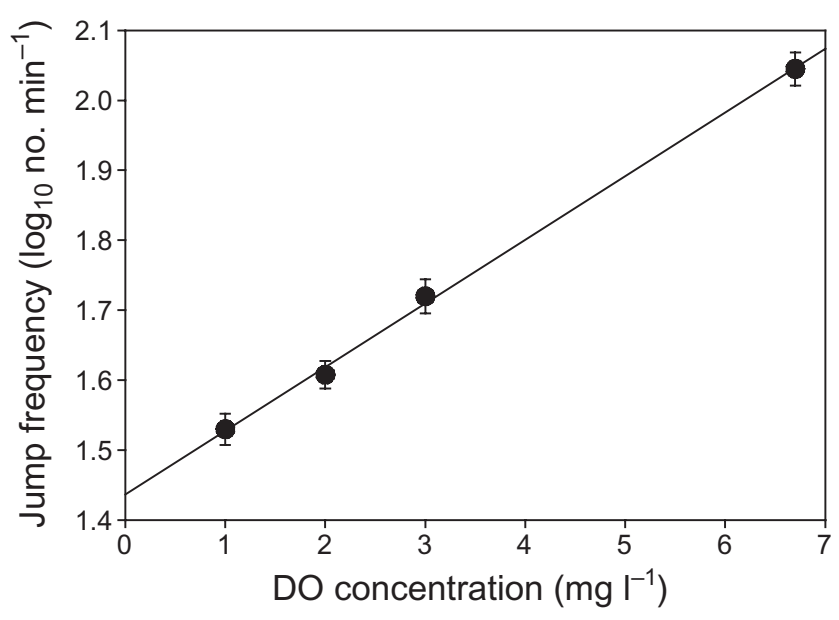

Fig. 3. Acartia tonsa. Jump frequency of copepods under reduced (1.0, 2.0 and $3.0 \mathrm{mg} \mathrm{l}^{-1}$ ) and air-saturated (approximately $7 \mathrm{mg} \mathrm{l}^{-1}$ ) dissolved oxygen (DO) concentrations. Symbols represent the mean jumping frequency $\pm 1 \mathrm{SE}$ of mean. Equation of line is $y=0.09 x+1.44, \mathrm{R}^{2}=0.99, t=21.12, \mathrm{df}=2$,

$$
\mathrm{p}<0.002
$$

low of 38.3 jumps $\min ^{-1}(\mathrm{SE}=1.8)$ in the $1.0 \mathrm{mg} \mathrm{l}^{-1}$ treatment to a high of 127.8 jumps $\min ^{-1}(\mathrm{SE}=6.9)$ in the air-saturated treatment. Linear regression of logtransformed jump frequency against DO concentration was significant $\left(\mathrm{R}^{2}=0.996, t=21.12, \mathrm{df}=2, \mathrm{p}=0.002\right)$.

\section{DISCUSSION}

Results from this study indicate that consumption of calanoid copepods by large Mnemiopsis leidyi ctenophores (mean $=22.5 \mathrm{ml}$, range $=7$ to $46 \mathrm{ml}$ ) was greater in low dissolved oxygen (DO) environments than under normoxic conditions. In contrast, consumption by small ctenophores (mean $2.9 \mathrm{ml}$, range $=1$ to $10 \mathrm{ml}$ ) was not influenced by DO concentrations $\geq 1 \mathrm{mg} \mathrm{l}^{-1}$, just as consumption of ichthyoplankton (fish eggs and larvae) by $M$. leidyi (average volume $=15.6 \mathrm{ml}$, range $=7$ to $25 \mathrm{ml}$ ) is not affected by oxygen concentrations greater than or equal to $1.5 \mathrm{mg} \mathrm{l}^{-1}$ (S. Kolesar et al. unpubl. data). Because consumption rates of large ctenophores feeding on zooplankton prey appear to be affected by the low DO at which they are found in the field, the location within the water column at which encounters occur, the size distribution of ctenophores, as well as vertical overlap between predator and prey may all be extremely important in determining the overall effect that hypoxia has on trophic interactions (Keister et al. 2000, Breitburg et al. 2003).

Bottom-layer hypoxia has a great influence on the vertical distribution of zooplankton and gelatinous predators in Chesapeake Bay and its tributaries, but the DO concentration eliciting avoidance varies among species (Breitburg et al. 2003, Decker et al. 2003). As a result, the presence of low DO concentrations could affect overlap of and encounters between Mnemiopsis leidyi and Acartia tonsa copepods. Field sampling in both the mainstem Chesapeake Bay (Roman et al. 1993) and the Patuxent River (Keister et al. 2000, J. Purcell et al. unpubl. data) indicate that $A$. tonsa is less abundant in the bottom layer when DO concentrations are low than when they are high. The proportion of $A$. tonsa found in the bottom layer of the Patuxent River declines as DO concentrations fall below 2.5 to $3 \mathrm{mg} \mathrm{l}^{-1}$. In contrast, high proportions of $M$. leidyi were found in the bottom layer at DO concentrations as low as $1.3 \mathrm{mg} \mathrm{l}^{-1}$ (Keister et al. 2000, Breitburg et al. 2003). As a result, vertical overlap between $M$. leidyi and $A$. tonsa would be reduced when bottom DO concentrations are 1 to $2 \mathrm{mg} \mathrm{l}^{-1}$. In addition, because $A$. tonsa actively avoids the hypoxic bottom layer in a stratified water column (Decker et al. 2003), per capita consumption of this prey by ctenophores may be highest in the volume of water within and above the pycnocline and oxycline. 
Our estimate of average ctenophore clearance rates of copepods (i.e. $1.0 \mathrm{l} \mathrm{cleared} \mathrm{h}^{-1}$ ctenophore $^{-1}$ or $23.3 \mathrm{l}$ cleared ctenophore ${ }^{-1} \mathrm{~d}^{-1}$, based on an average ctenophore volume of $15 \mathrm{ml}$ ) is comparable to estimates measured by other investigators (reviewed in Purcell et al. 2001b). Previous estimates standardized for a $40 \mathrm{ml}$ ctenophore range from 16.8 to $52.8 \mathrm{l}$ cleared ctenophore ${ }^{-1} \mathrm{~d}^{-1}$, increasing with container size. Ctenophore volumes in our study ranged from 1 to $46 \mathrm{ml}$. The wide size range of ctenophores used in the predation experiment may be responsible, in part, for the scatter in the number of prey items consumed (Fig. 1). The experimental containers used here were fairly small (90 l), and our clearance estimate was more similar to those previously estimated in small containers.

Martinussen \& Båmstedt $(1999,2001)$ stressed the importance of performing digestion experiments whenever gut contents are used to measure consumption rates of gelatinous predators, because ambient conditions can have significant effects on digestion rates. Because we used gut contents to measure consumption by ctenophores in this study, we tested the effects of DO concentration on the rate of extracellular digestion in Mnemiopsis leidyi. DO concentration had no effect on the rate at which copepods are broken down in $M$. leidyi's pharynx. In addition, hypoxia did not cause ctenophores to expel undigested prey from their mouths.

Predation is the final outcome of the probability of encounters between predator and prey and the probability of prey escape. In addition to the effect of shifts in vertical distributions discussed above, rates of prey encounter depend in part on relative swimming speeds of predator and prey, with faster swimming prey being encountered more frequently than slower prey (Gerritsen \& Strickler 1977). Low-DO concentrations reduced the jumping frequencies of Acartia tonsa copepods. Therefore, one would expect encounter rates of copepods with predatory ctenophores also to decline with decreasing DO concentrations. However, we showed that predation rates of large ctenophores tended to be higher in moderately hypoxic DO treatments, and clearance rates of large ctenophores were higher at all reduced oxygen concentrations tested than in airsaturated controls (Fig. 1A, Table 2). It is possible that the reduced jump rates we measured were a general indication of reduced locomotory abilities of copepods under hypoxic conditions and that escape behavior of copepods is also compromised by low oxygen. If so, our results suggest that hypoxia-induced changes in escape rates are more important than changes in encounter rates in determining the ultimate effect of hypoxia on consumption of copepods by large ctenophores. However, the relative importance of encounter and escape rates may differ for small and large cteno- phores, leading to a net result of no effect of hypoxia on consumption by small ctenophores. In order to resolve this issue, future research should investigate the effects of DO concentrations on actual encounters between ctenophores and zooplankton, including the influence of DO on the swimming speeds of all ctenophore size classes and on the escape reactions of A. tonsa.

Future studies should also consider the effects of hypoxia on ctenophore predation of other dominant zooplankters in the Chesapeake Bay system. For example, the naupliar stages of Acartia tonsa are extremely abundant in summer (Roman et al. 1993) and are important prey of Mnemiopsis leidyi in Chesapeake Bay (Purcell et al. 2001b). A. tonsa adults are less tolerant of low DO than are nauplii (Stalder \& Marcus 1997). Therefore, the effect of hypoxia on ctenophores feeding on adults and copepodites (this study) may differ from that of ctenophores feeding on nauplii. The mechanisms by which lobate ctenophores encounter and capture their prey also differ, depending on prey type and prey behavior (Larson 1988, Waggett \& Costello 1999). Actively-swimming adult A. tonsa first contact the inner surfaces of the ctenophore's lobes, whereas, weakly-swimming A. tonsa nauplii first contact the tentillae within the lobes of $M$. leidyi (Wagget \& Costello 1999). Due to these distinct encounter mechanisms, low DO may affect capture and escape of adult and naupliar stages of $A$. tonsa differently.

Low DO may have pronounced effects on the trophic interactions involving gelatinous predators in Chesapeake Bay. Similar to what we observed for small Mnemiopsis leidyi, predation by Chrysaora quinquecirrha medusae on copepods was unaffected by DO concentrations $\geq 1.5 \mathrm{mg} \mathrm{l}^{-1}$ (Breitburg et al. 1994, 1997). In contrast, C. quinquecirrha medusa predation on naked goby larvae Gobiosoma bosc was much greater at low DO concentrations $\left(1.5 \mathrm{mg} \mathrm{l}^{-1}\right)$ than in air-saturated conditions, whereas predation on fish eggs (Anchoa mitchilli) decreased in low DO (Breitburg et al. 1994, 1997). In striking contrast with the medusae, low DO concentrations resulted in decreased consumption of fish larvae by juvenile and adult fishes (Morone saxatilus and G. bosc, respectively) (Breitburg et al. 1994, 1997). These previous studies of $C$. quinquecirrha along with studies of $M$. leidyi (this study, and S. Kolesar et al. unpubl. data) suggest that hypoxia tolerance of $M$. leidyi ctenophores and C. quinquecirrha medusae (as compared with hypoxia-sensitive fishes: Breitburg et al. 2003) may enable gelatinous species to inhabit and be effective predators in regions of low DO that exclude vertebrate predators with high respiratory demands. This may lead to dominance of gelatinous predators over fishes in regions affected by severe 
hypoxia, and could potentially alter energy pathways in these systems (Breitburg et al. 1999, Purcell et al. 2001a).

Acknowledgements. We thank, in particular, X. Ma as well as L. Brink, R. Condon, K. Crawford, D. Davis, E. Haberkern, S. Kolesar, C. Stringer and W. Yates, for their help in collecting animals and conducting laboratory experiments. We also thank M. Bundy, J. Costello, P. Kremer, M. Olson and P. Turner for insightful discussions. This research was funded by Environmental Protection Agency STAR award No. 82709701-0 to D.L.B., J.E.P., M.B.D. and K. A. Rose.

\section{LITERATURE CITED}

Bejda AJ, Studholme AL, Olla BL (1987) Behavioral responses of red hake, Urophycis chuss, to decreasing concentrations of dissolved oxygen. Environ Biol Fishes 19:261-268

Bell GW, Eggleston DB, Wolcott, TG (2003) Behavioral responses of free-ranging blue crabs to episodic hypoxia. I. Movement. Mar Ecol Prog Ser 259:215-225

Boesch DF, Brinsfield RB, Magnien RE (2001) Chesapeake Bay eutrophication: scientific understanding, ecosystem restoration, and challenges for agriculture. J Environ Qual 30:303-320

Breitburg DL, Steinberg N, DeBeau S, Cooksey C, Houde ED (1994) Effects of low oxygen on predation on estuarine fish larvae. Mar Ecol Prog Ser 104:235-246

Breitburg DL, Loher T, Pacey CA, Gerstein A (1997) Varying effects of low dissolved oxygen on trophic interactions in an estuarine food web. Ecol Monogr 67:489-507

Breitburg DL, Rose KA, Cowan JH (1999) Linking water quality to larval survival: predation mortality of fish larvae in an oxygen-stratified water column. Mar Ecol Prog Ser 187: $39-54$

Breitburg DL, Pihl L, Kolesar SE (2001) Effects of low dissolved oxygen on the behavior, ecology and harvest of fishes: a comparison of the Chesapeake Bay and BalticKattegat systems. In: Rabalais NN, Turner RE (eds) Coastal hypoxia: consequences for living resources and ecosystems. Coastal \& Estuarine Studies 58, American Geophysical Union, Washington, DC, p 241-268

Breitburg DL, Adamack A, Kolesar SE, Decker MB, Rose KA, Purcell JE, Keister JE, Cowan JH (2003) The pattern and influence of low dissolved oxygen in the Patuxent River, a seasonally hypoxic estuary. Estuaries 26:280-297

Caddy JF (1993) Toward a comparative evaluation of human impacts on fishery ecosystems of enclosed and semienclosed seas. Rev Fish Sci 1:57-95

Cowan JH, Houde ED (1992) Size-dependent predation on marine fish larvae by ctenophores, scyphomedusae, and planktivorous fish. Fish Oceanogr 1:113-126

Cowan JH, Houde ED (1993) Relative predation potentials of scyphomedusae, ctenophores, and planktivorous fish on ichthyoplankton in Chesapeake Bay. Mar Ecol Prog Ser 95:55-65

Decker MB, Breitburg DL, Marcus NH (2003) Geographical differences in the behavioral response of zooplankton to hypoxia: local adaptation to an anthropogenic stressor? Ecol Appl 13:1104-1109

Diaz RJ (2001) Overview of hypoxia around the world. J Environ Qual 30:275-281

Dressel DM, Heinle DR, Grote MC (1972) Vital staining to sort dead and live copepods. Chesapeake Sci 13:156-159
Elmgren R (1989) Man's impact on the ecosystem of the Baltic Sea: energy flows today and at the turn of the century. Ambio 18:326-332

Fleming JM, Coughlan J (1978) Preservation of vitally stained zooplankton for live/dead sorting. Estuaries 1:135-137

Forward RB (1988) Diel vertical migration: zooplankton photobiology and behaviour. Oceanogr Mar Biol Annu Rev 26:361-393

Gerritsen J, Strickler JR (1977) Encounter probabilities and community structure in zooplankton: a mathematical model. J Fish Res Board Can 34:73-82

Howell P, Simpson D (1994) Abundance of marine resources in relation to dissolved oxygen in Long Island Sound. Estuaries 17:384-402

Jonas R (1992) Microbial processes, organic matter and oxygen demand in the water column. In: Smith DE, Leffler M, Mackiernan $\mathrm{G}$ (eds) Oxygen dynamics in the Chesapeake Bay: a synthesis of recent research. Maryland Sea Grant, College Park, MD, p 113-148

Keister JE, Houde ED, Breitburg DL (2000) Effects of bottomlayer hypoxia on abundances and depth distributions of organisms in Patuxent River, Chesapeake Bay. Mar Ecol Prog Ser 205:43-59

Kennedy VS (1990) Anticipated effects of climate change on estuarine and coastal fisheries. Fisheries 15(6):16-24

Kolar CS, Rahel FJ (1993) Interaction of a biotic factor (predator presence) and an abiotic factor (low oxygen) as an influence on benthic invertebrate communities. Oecologia 95:210-219

Kremer P (1979) Predation by the ctenophore Mnemiopsis leidyi in Narragansett Bay, Rhode Island. Estuaries 2:97-105

Kremer P, Reeve MR (1989) Growth dynamics of a ctenophore (Mnemiopsis) in relation to variable food supply. II. Carbon budgets and growth model. J Plankton Res 11:553-574

Larson RJ (1987) In situ feeding rates of the ctenophore Mnemiopsis mccradyi. Estuaries 10:87-91

Larson RJ (1988) Feeding and functional morphology of the lobate ctenophore Mnemiopsis mccradyi. Estuar Coast Shelf Sci 27:495-502

Marcus NH (2001) Zooplankton: responses to and consequences of hypoxia. In: Rabalais NN, Turner RE (eds) Coastal hypoxia: consequences for living resources and ecosystems. Coastal \& Estuarine Studies 58, American Geophysical Union, Washington, DC, p 49-60

Martinussen MB, Båmstedt U (1999) Nutritional ecology of gelatinous planktonic predators. Digestion rate in relation to type and amount of prey. J Exp Mar Biol Ecol 232:61-84

Martinussen MB, Båmstedt U (2001) Digestion rate in relation to temperature of two gelatinous planktonic predators. Sarsia 86:21-35

Miller DC, Poucher SL, Coiro L (2002) Determination of lethal dissolved oxygen levels for selected marine and estuarine fishes, crustaceans, and a bivalve. Mar Biol 140:287-296

Officer CB, Biggs RB, Taft JL, Cronin LE, Tyler MA, Boynton WR (1984) Chesapeake Bay anoxia: origin, development and significance. Science 223:22-27

Petersen JK, Pihl L (1995) Responses to hypoxia of plaice, Pleuronectes platessa, and dab, Limanda limanda, in the south-east Kattegat: distribution and growth. Environ Biol Fish 43:311-321

Pihl L, Baden SP, Diaz RJ, Schaffner LC (1992) Hypoxiainduced structural changes in the diet of bottom-feeding fish and crustacea. Mar Biol 112:349-361

Poulin R, Wolf NG, Kramer DL (1987) The effect of hypoxia on the vulnerability of guppies (Poecilia reticulata, Poeciliidae) to an aquatic predator (Astronotus ocellatus, Cichlidae). Environ Biol Fish 20:285-292 
Purcell JE, Decker MB (2005) Effects of climate on relative predation by Scyphomedusae and ctenophores in Chesapeake Bay during 1987-2000. Limnol Oceanogr (in press)

Purcell JE, Nemazie DA, Dorsey SE, Houde ED, Gamble JC (1994a) Predation mortality of bay anchovy (Anchoa mitchilli) eggs and larvae due to scyphomedusae and ctenophores in Chesapeake Bay. Mar Ecol Prog Ser 114: 47-58

Purcell JE, White JR, Roman MR (1994b) Predation by gelatinous zooplankton and resource limitation as potential controls of Acartia tonsa copepod populations in Chesapeake Bay. Limnol Oceanogr 39:263-278

Purcell JE, Breitburg DL, Decker MB, Graham WM, Youngbluth MJ, Raskoff K (2001a) Pelagic cnidarians and ctenophores in low dissolved oxygen environments: a review. In: Rabalais NN, Turner RE (eds) Coastal hypoxia: consequences for living resources and ecosystems. Coastal \& Estuarine Studies 58, American Geophysical Union, Washington, DC, p 77-100

Purcell JE, Shiganova TA, Decker MB, Houde ED (2001b) The ctenophore Mnemiopsis in native and exotic habitats: US estuaries versus the Black Sea basin. Hydrobiologia 451: 145-176

Rabalais NN, Turner RE, Wiseman WJ Jr, Boesch DF (1991) A brief summary of hypoxia on the northern Gulf of Mexico continental shelf: 1985-1988. In: Tyson RV, Person TH (eds) Modern and ancient continental shelf anoxia. Geological Society, London, p 35-47

Rabalais NN, Turner RE, Dortch Q, Justic D, Bierman VJ, Wiseman WJ (2002) Nutrient-enhanced productivity in the northern Gulf of Mexico: past, present, future. Hydrobiologia 475/476:39-63

Rahel FJ, Kolar CS (1990) Trade-offs in the response of mayflies to low oxygen and fish predation. Oecologia 84: $39-44$

Renaud ML (1986) Hypoxia in Louisiana coastal waters during 1983: implication for fisheries. Fish Bull 84:19-26

Roman MR, Gauzens AL, Rhinehart WK, White JR (1993)

Editorial responsibility: Kenneth Sherman (Contributing Editor), Narragansett, Rhode Island, USA
Effects of low oxygen waters on Chesapeake Bay zooplankton. Limnol Oceanogr 38:1603-1614

Rosenburg R, Elmgren R, Fleischer S, Jonsson P, Presson G, Dahlin H (1990) Marine eutrophication case studies in Sweden: a synopsis. Ambio 19:102-108

Rudstam LG, Magnuson JJ (1985) Predicting the vertical distribution of fish populations: analysis of cisco, Coregonus artedii, and yellow perch, Perca flavescens. Can J Fish Aquat Sci 42:1178-1188

Sanford LP, Sellner KG, Breitburg DL (1990) Covariability of dissolved oxygen with physical processes in the summertime Chesapeake Bay. J Mar Res 48:567-590

Stalder LC, Marcus NH (1997) Zooplankton responses to hypoxia: behavioral patterns and survival of three species of calanoid copepods. Mar Biol 127:599-607

Sterns DE, Forward RB (1984) Photosensitivity of the calanoid copepod Acartia tonsa. Mar Biol 82:85-89

Swanson RL, Parker CA (1988) Physical environmental factors contributing to recurring hypoxia in the New York Bight. Trans Am Fish Soc 117:37-47

Taft JL, Taylor WR, Hartwig EO, Loftus R (1980) Seasonal oxygen depletion in Chesapeake Bay. Estuaries 4:242-247

Taylor DL, Eggleston DB (2000) Effects of hypoxia on an estuarine predator-prey interaction: foraging behavior and mutual interference in the blue crab Callinectes sapidus and the infaunal clam prey Mya arenaria. Mar Ecol Prog Ser 196:221-237

Tiselius P, Jonsson PR (1997) Effects of copepod foraging behavior on predation risk: an experimental study of the predatory copepod Pareuchaeta norvegica feeding on Acartia clausi and A. tonsa (Copepoda). Limnol Oceanogr 42:164-170

Turner RE, Shroeder WE, Wiseman WJ Jr (1987) The role of stratification in the deoxygenation of Mobile Bay and adjacent shelf bottom waters. Estuaries 19:13-20

Waggett R, Costello JH (1999) Capture mechanisms used by the lobate ctenophore, Mnemiopsis leidyi, preying on the copepod Acartia tonsa. J Plankton Res 21:2037-2052

Submitted: September 1, 2003; Accepted: May 27, 2004

Proofs received from author(s): September 27, 2004 